\title{
Comparison of Patient Satisfaction and Cost in Spinal and General Anesthesia for Lumbar Disc Surgery
}

\section{Lomber Disk Cerrahisinde Spinal ve Genel Anestezinin Hasta Memnuniyeti ve Maliyet Açusından Karșılaștırılması}

Cagil VURAL, Dilek YORUKOGLU

Ankara University, Faculty of Medicine, Department of Anesthesiology and Reanimation, Ankara, Turkey

Corresponding Author: Cagil VURAL / E-mail: cagilvural@hotmail.com

\begin{abstract}
AIM: The aim of this study was to evaluate patient satisfaction and cost in spinal and general anesthesia for lumbar disc surgery.

MATERIAL and METHODS: The study was performed on 66 ASA class I-II patients with one level lumbar disc herniation (LDH). In this prospective study, patients were assigned randomly to either spinal anesthesia or general anesthesia groups. Hemodynamic variables, intraoperative opioid requirements, postoperative pain scores and analgesic requirements and complications were recorded. Patients were handed a questionnaire about the procedure they underwent to determine patient satisfaction. The costs of preoperative and postoperative anesthesia procedures, medications, and hospitalization were calculated individually.

RESULTS: Spinal anesthesia and general anesthesia were similar concerning hemodynamic stability, first urination time, first mobilization time, postoperative analgesic requirement, and pain. Patients in group S needed less additional dose of fentanyl intraoperatively than the patients in group G. Patient satisfaction was significantly higher in Group S when compared to Group G. Total cost was higher in Group G compared to Group S.
\end{abstract}

CONCLUSION: We conclude that successful LDH surgery can be performed using either anesthesia type. As long as patients are selected carefully, spinal anesthesia is a safe, comfortable, and a more economical alternative.

KEYWORDS: Lumbar disc surgery, Spinal anesthesia, General anesthesia, Patient satisfaction, Cost

öz

AMAÇ: Bu çalışmanın amacı, lomber disk cerrahisinde spinal ve genel anesteziyi hasta memnuniyeti ve maliyet açısından karşılaştırmaktır.

YÖNTEM ve GEREÇLER: Çalışma tek seviye lomber disk herniasyonu (LDH) olan 66 ASA I-II hasta üzerinde yapıldı. Bu prospektif çalışmada, hastalar randomize olarak spinal anestezi veya genel anestezi grubuna dahil edildi. Hemodinamik değişkenler, intraoperatif opioid ihtiyaçları, postoperatif ağrı skorları ve analjezik ihtiyaçları kaydedildi. Hastalara hasta memnuniyetini belirlemek için uygulanan işlem süreciyle ilgili anket verildi. Ameliyat öncesi ve sonrası anestezi işlemleri, ilaçlar ve yatış maliyetleri ayrı ayrı hesaplanmıştır.

BULGULAR: Spinal ve genel anestezi hemodinamik stabilite, ilk idrar zamanı, ilk mobilizasyon zamanı, postoperatif ağrı ve analjezik ihtiyacı açısından benzerdi. Grup S hastalarda intraoperatif ek doz fentanyl ihtiyacı daha azdı. Hasta memnuniyeti Grup S hastalarda anlamlı olarak daha yüksekti. Toplam maliyet Grup G'de daha yüksekti.

SONUÇ: Başarılı LDH cerrahisi her iki anestezi yöntemini kullanarak yapılabilir. Hastalar özenle seçildiğinde spinal anestezinin güvenli, konforlu ve daha ekonomik bir alternatif olduğu sonucuna vardık.

ANAHTAR SÖZCÜKLER: Lomber disk cerrahisi, Spinal anestezi, Genel anestezi, Hasta memnuniyeti, Maliyet

\section{INTRODUCTION}

Lumbar disc hernia (LDH) is one of the most frequent reasons for back pain (7). It causes significant productivity loss and the main treatment is surgery (21). LDH is characterized by herniation of intervertebral disc into the spinal canal. Motor function impairment and sciatalgia, which continue for 3- 4 weeks, suggests surgical treatment (17). General anesthesia $(G A)$ is the most common method for LDH surgery; however, epidural (EA) and spinal (SA) anesthesia is also used for discectomy, laminectomy and similar elective spinal surgeries $(21,6)$.

Both general and spinal anesthesia are routine practice in our hospital. Spinal anesthesia is used whenever the patient fulfills the criteria and the surgeon feels comfortable about it.

The aim of this study was to compare patient satisfaction and cost in general anesthesia and spinal anesthesia for lumbar disc surgery. 


\section{MATERIAL and METHODS}

After obtaining approval from Ankara University Medical School Ethical Committee the study was performed on 66 ASA class I-II patients (23- 74 year old) with one level lumbar disc herniation. All the patients were informed and written consent was obtained. Patients with clinically significant cardiovascular, neuromuscular, renal, hepatic or metabolic disease, obesity, bleeding abnormalities and history of allergic reactions to local anesthetic drugs, were excluded from the study.

All patients were premedicated with midazolam (Dormicum $5 \mathrm{mg} / 5 \mathrm{ml}$, DEVA, Turkiye) $0.03 \mathrm{mg} / \mathrm{kg}$ intravenous, ranitidine (Ulcuran $25 \mathrm{mg} / \mathrm{ml}$, Yavuz llac, Turkiye) $100 \mathrm{mg}$ intravenously and atropine $0.5 \mathrm{mg}$ (Atropin Sulfat $0.5 \mathrm{mg} / \mathrm{ml}$, Biofarma, Turkiye) intramuscularly 1 hour before the operation. In the operation room, an $18 \mathrm{G}$ intravenous catheter was introduced into a peripheral vein. Routine monitoring consisted of electrocardiogram, pulse oximetry, and noninvasive blood pressure measurement.

In this prospective study, patients were assigned randomly to either spinal anesthesia or general anesthesia.

Group G (General Anesthesia): Thiopental $6 \mathrm{mg} / \mathrm{kg}$ (Pental $0.5 \mathrm{gr}$, I.E. Ulagay, Turkiye) intravenous and fentanyl $1.5 \mu \mathrm{gr} / \mathrm{kg}$ (Fentanyl $0.05 \mathrm{mg} / \mathrm{ml}$, Johnson\&Johnson, U.S.) was administered for anesthesia induction. Endotracheal intubation was facilitated with rocuronium bromide $0.6 \mathrm{mg} /$ $\mathrm{kg}$ (Esmeron $50 \mathrm{mg} / 5 \mathrm{ml}$, Schering Plough, U.S.) intravenous and anesthesia was maintained with 5-6\% desflurane (Suprane volatil $240 \mathrm{ml}$, Eczacibasi Baxter, Turkiye) in 50\% nitrous oxide in oxygen. Once the patients were intubated, they were placed in the prone position on a standard operating table using a flexed position. Anesthetics were modified to maintain hemodynamic variables within $10 \%$ of baseline values. Fentanyl $0.5 \mathrm{mg} / \mathrm{kg}$ (Fentanyl $0.05 \mathrm{mg} / \mathrm{ml}$, Johnson\&Johnson, U.S.) was administered i.v. when heart rate and mean blood pressure exceeded $20 \%$ of baseline values.

Group S (Spinal Anesthesia): Spinal anesthesia was applied in the left decubitus position in all patients. The subarachnoid space was entered at the L2-3 or L3-4 interspace via the midline approach using a $25 \mathrm{G}$ spinal needle. Hyperbaric 15 mg $0.5 \%$ bupivacaine (Marcaine spinal heavy $\% 0.54 \mathrm{ml}$, Astra Zeneca, U.K.) was injected intrathecally and the patients were immediately turned to the supine position. When a stable level of spinal anesthesia at T6-T10 was achieved, the patient was rolled to prone position allowing them to position themselves into a comfortable position on the operating table. Patients received 1-2 L/min oxygen via nasal cannula during the operation.

Heart rate (HR), systolic blood pressure (SBP), mean arterial blood pressure (MABP) and diastolic blood pressure (DBP), were recorded before anesthesia, every 5 minutes during the operation, at the end of surgery and 60, 90, 120, 240 minutes and 24 hour after surgery.
Intraoperative complications, intraoperative additional fentanyl requirements and postoperative complications were recorded. Patients were observed in the recovery room for 30 minutes after the surgery.

Visual Analog Scale (VAS) scores were recorded at the end of surgery (0 hour) and 1, 3, 6, 12, 24 hours postoperatively. The 10-point linear Visual Analogue Scale was used to assess the severity of pain, and the rating was as follows: ' 0 ' no pain and ' 10 ' maximum imaginable pain.

Before their discharge from the hospital, patients were handed a questionnaire about the procedure they underwent to determine patient satisfaction (Table I).

Datas were evaluated using SPSS 18.0 (Statistical Program for Social Sciences, Chicago, II, U.S). The Levene test was used for normality to detect whether data was along normal measures. Data was presented as mean and standard deviation if distribution was parametric or expressed as median and 2575 percentile if distribution was non-parametric. Chi square or Fisher's Exact test was used where appropriate to evaluate categorized data. Additionally, the t-test and Mann Withney $\mathrm{U}$ tests were used for analysis of continuing data. $\mathrm{P}<0.05$ was accepted as statistically significant.

\section{RESULTS}

There was no statistical demographic difference between the two groups ( $p>0.05$ ).

Heart rates, systolic blood pressure, diastolic blood pressure and mean blood pressures did not differ between the two groups ( $p>0.05$ ) (Table II).

Intraoperative complications were rare and not significantly different between two groups (Table III).

Patients in the spinal anesthesia group needed less additional dose of fentanyl intraoperatively than the patients in general anesthesia group $(p=0,022)$ (Table IV).

Table I: Postoperative Questionnaire

\begin{tabular}{|l|c|c|c|}
\hline & 0 & 1 & 2 \\
\hline Global satisfaction & Yes & Not sure & No \\
\hline Willingness to repeat & Yes & Not sure & No \\
\hline Recommending the procedure & Yes & Not sure & No \\
\hline
\end{tabular}

Table II: Hemodynamic Measurements

\begin{tabular}{|l|c|c|c|}
\hline & Group S & Group G & P \\
\hline Heart rate & $82 \pm 13$ & $87 \pm 17$ & 0,350 \\
\hline $\begin{array}{l}\text { Systolic blood pressure } \\
\text { (mmHg) }\end{array}$ & $119 \pm 12$ & $122 \pm 25$ & 0,640 \\
\hline $\begin{array}{l}\text { Mean blood pressure } \\
\text { (mmHg) }\end{array}$ & $81 \pm 12$ & $88 \pm 18$ & 0,226 \\
\hline $\begin{array}{l}\text { Diastolic blood pressure } \\
\text { (mmHg) }\end{array}$ & $63 \pm 10$ & $71 \pm 16$ & 0,126 \\
\hline
\end{tabular}


Postoperative complications showed no significant difference between the groups ( $p>0.05$ ) (Table V).

Table III: Intraoperative Complications

\begin{tabular}{|l|c|c|c|}
\hline Spinal & $\begin{array}{c}\text { Group } \\
\text { General }\end{array}$ & Total \\
\hline None & 12 & 11 & 23 \\
\hline Hypotension & 11 & 10 & 21 \\
\hline Surgical bleeding & 0 & 3 & 3 \\
\hline Intraoperative pain & 1 & 0 & 1 \\
\hline Nausea and vomiting & 2 & 0 & 2 \\
\hline Tachycardia & 0 & 1 & 1 \\
\hline $\begin{array}{l}\text { Hypertension and } \\
\text { tachycardia }\end{array}$ & 0 & 2 & 2 \\
\hline
\end{tabular}

Table IV: Intraoperative Fentanyl Requirement

\begin{tabular}{|c|c} 
Spinal (n: 33) & General (n: 33) \\
\hline $4^{*}$ & 13
\end{tabular}

In Group S, at postoperative 0, 1 and 3 hours VAS pain scores were significantly lower than Group $\mathrm{G}(\mathrm{P}<0.05)$ (Table VI).

There was no significant difference in postoperative first analgesic demand between the two groups. First mobilization time and first urination times were similar in two groups ( $p>0.05)$. Hospital stay was one day in $75 \%$ of the atients and there was no significant difference between the two groups.

Patient satisfaction (global satisfaction, willingness to repeat and recommending the procedure) was significantly higher in Group S when compared to Group G $(p<0.05)$ (Table VII).

Table V: Postoperative Complications

\begin{tabular}{|l|c|c|c|}
\hline None & Spinal & $\begin{array}{c}\text { Group } \\
\text { General }\end{array}$ & Total \\
\hline Headache & 8 & 7 & 15 \\
\hline Nausea and vomiting & 4 & 3 & 7 \\
\hline Urinary retention & 0 & 6 & 6 \\
\hline Hypotension & 0 & 0 & 0 \\
\hline
\end{tabular}

${ }^{*} p=0,022$

Table VI: Postoperative VAS Scores

\begin{tabular}{l|l|c|c|c|c|c}
\hline & $\begin{array}{c}\text { VAS } \\
\text { 0 hour }\end{array}$ & $\begin{array}{c}\text { VAS } \\
1 \text { hour }\end{array}$ & $\begin{array}{c}\text { VAS } \\
3 \text { hours }\end{array}$ & $\begin{array}{c}\text { VAS } \\
6 \text { hours }\end{array}$ & $\begin{array}{c}\text { VAS } \\
12 \text { hours }\end{array}$ & $\begin{array}{c}\text { VAS hours } \\
24\end{array}$ \\
\hline Group S & $0(0-0)$ & $0(0-3)$ & $2(0-4)$ & $3(2-3)$ & $2(1-3)$ & $2(1-3)$ \\
\hline Group G & $2(0-5)$ & $3(2-4)$ & $4(2-4)$ & $3(2-4)$ & $2(2-3)$ & $2(1-3)$ \\
\hline$p$ & $<0,001$ & 0,001 & 0,003 & 0.942 & 0.113 & 0,564
\end{tabular}

Table VII: Patient Satisfaction

\begin{tabular}{|c|c|c|c|c|c|c|c|c|c|}
\hline & \multicolumn{3}{|c|}{ Global satisfaction } & \multicolumn{3}{|c|}{ Willingness to repeat } & \multicolumn{3}{|c|}{ Recommending procedure } \\
\hline & Yes & Not sure & No & Yes & Not sure & No & Yes & Not sure & No \\
\hline Spinal & $\begin{array}{c}31^{*} \\
(\% 94)\end{array}$ & $\begin{array}{c}2 \\
(\% 6)\end{array}$ & 0 & $\begin{array}{c}28^{*} \\
(\% 85)\end{array}$ & $\begin{array}{c}5 \\
(\% 15)\end{array}$ & 0 & $\begin{array}{c}31^{*} \\
(\% 94)\end{array}$ & $\begin{array}{c}1 \\
(\% 3)\end{array}$ & $\begin{array}{c}1 \\
(\% 3)\end{array}$ \\
\hline General & $\begin{array}{c}24 \\
(\% 73)\end{array}$ & $\begin{array}{c}4 \\
(\% 12)\end{array}$ & $\begin{array}{c}5 \\
(\% 15)\end{array}$ & $\begin{array}{c}17 \\
(\% 52)\end{array}$ & $\begin{array}{c}4 \\
(\% 12)\end{array}$ & $\begin{array}{c}12 \\
(\% 36)\end{array}$ & $\begin{array}{c}18 \\
(\% 55)\end{array}$ & $\begin{array}{c}3 \\
(\% 9)\end{array}$ & $\begin{array}{c}12 \\
(\% 36)\end{array}$ \\
\hline
\end{tabular}

${ }^{*} p<0,05$.

Table VIII: Costs (\$)

\begin{tabular}{|c|c|c|c|}
\hline & Group S & Group G & $\mathbf{p}$ \\
\hline Anesthetic procedure & $98,02 \pm 0,00$ & $73,36 \pm 0,00$ & $<0,001$ \\
\hline Surgical procedure & $235,95 \pm 2,94$ & $234,96 \pm 3,45$ & 0,216 \\
\hline Preoperative evaluation & $71,57 \pm 8,86$ & $72,61 \pm 7,8$ & 0,611 \\
\hline Anesthetic medication & $26,07 \pm 8,72$ & $78,18 \pm 39,1$ & $<0,001$ \\
\hline Anesthetic equipment & $39,71 \pm 13,87$ & $45 \pm 21,2$ & 0,234 \\
\hline Hospital stay & $15(0-15)$ & $15(0-15)$ & 0,223 \\
\hline Total cost & $476,81 \pm 16,67$ & $511,93 \pm 44,67$ & $<0,001$ \\
\hline
\end{tabular}


Total cost was higher in Group G compared to Group S $(p<0.001)$. Costs for preoperative evaluation, equipment, and hospital stay were similar in two groups $(p>0.05)$. The cost for the spinal anesthesia procedure was higher than the general anesthesia procedure $(p<0.001)$. Cost of medication for general anesthesia was higher than spinal anesthesia $(p<0.001)$ (Table VIII).

\section{DISCUSSION}

Our results confirm that patient satisfaction was better and total cost was less for spinal anesthesia than general anesthesia for lumbar disc surgery. Intraoperative and postoperative complications were similar in terms of safety and efficacy; we can say that spinal anesthesia is at least comparable to general anesthesia.

Although there is no scientific or clinical evidence that GA is superior to SA, GA is the widely accepted method for elective lumbar spine surgery. Probable reasons for this seems like surgeon bias and perhaps, the experience of the anesthesiologist and lack of exposure to the option of SA. However spinal anesthesia has become increasingly popular in recent years $(6,12,16)$. Studies have shown that spinal anesthesia has some advantages like less nerve injury, less corneal damage, less intraoperative bleeding and thromboembolism, decreased analgesic medication requirements and fewer side effects such as nausea and vomiting $(6,14,10)$. These advantages result in shorter hospital stay and reduced cost $(5,18)$. Spinal anesthesia has been in our routine practice for 5 years now. Two neurosurgeons are comfortable with the method and their patients undergo spinal anesthesia as long as there is no contraindication.

In some randomized prospective studies, it was reported that blood pressure and heart rate were lower in spinal anesthesia compared to general anesthesia during lumbar spine surgeries $(6,18)$. Other studies have reported that spinal anesthesia provides better hemodynamic intraoperative stability $(1,19,22)$. In our study, hemodynamic variables were similar in the two groups.

Complications such as nausea and vomiting are encountered less in spinal anesthesia resulting in increased patient comfort $(5,18,20)$. The use of $\mathrm{N}_{2} \mathrm{O}$, decreased gastric emptying time may contribute to increased incidents of nausea and vomiting in general anesthesia (11). In our study, we found the two groups statistically similar although nausea seemed to be more in the general anesthesia group.

In several studies, acute pain scores were found to be lower in spinal anesthesia than in general anesthesia $(10,1,4)$. McLain et al reported that postoperative pain, nausea and vomiting were less in the spinal anesthesia group compared to the general anesthesia group in patients that underwent lumbar laminectomy surgery (9). One of the factors that contribute to this circumstance is that spinal anesthesia inhibits nociceptive pathways and sensorial block takes longer to diminish than motor block (3). Patients usually do not complain of pain in the first few hours after spinal surgery. Although postoperative
VAS scores were significantly lower in SA patients in the first 3 hours, first analgesic requirement times were similar. The reason for this may be that patients who undergo GA are not able to express their need for analgesics due to the residual effects of GA.

It is known that urinary retention is a frequent complication after spinal anesthesia and this situation depends on bladder muscle relaxation. Urinary retention is usually encountered in patients who receive intrathecal opioids $(8,2)$. On the contrary, Silver et al reported that urinary retention was less in patients who had spinal anesthesia (13). In our study, spinal anesthesia was achieved with bupivacaine and none of the patients had urinary retention.

Hospitalization time is shorter in patients who undergo surgery with spinal anesthesia than general anesthesia, which is an advantage $(6,10,18)$. The reasons might be the low incidence of complications such as pain, nausea and vomiting and decreased requirement for postoperative care after spinal anesthesia. In our study, we did not find any difference between two groups regarding hospitalization time. Although the patients who underwent surgery under spinal anesthesia were fit to be discharged from the hospital on the same day, they preferred to stay the postoperative first night in the hospital. We have determined that carefully selected patients who undergo surgery with spinal anesthesia can easily go home after 6 hours of observation.

Schuster et al showed that spinal anesthesia is more economical than general anesthesia in their retrospective study, which aims to compare costs of regional anesthesia and general anesthesia techniques (13). It was defended in many studies that spinal anesthesia is superior to general anesthesia concerning easy application, cost, and less environmental pollution in lumbar disk hernia surgery $(6,12,16)$. We found that total cost for spinal anesthesia in LDH surgery was significantly lower than total cost for general anesthesia. The most important reason for this result is that the cost of medications used in spinal anesthesia is much lower than in general anesthesia. The instruments, gas, and intravenous medications used in general anesthesia contribute to a higher cost. On the other hand, complications after general anesthesia tend to increase the cost. In our study, we found that $\$ 35$ was saved in spinal anesthesia and if more patients get used to the idea of day surgery this will further decrease total cost.

We conclude that successful LDH surgery can be performed using either anesthesia type. As long as patients are selected carefully, spinal anesthesia is a safe, comfortable, and a more economical alternative.

\section{REFERENCES}

1. Becq $M C$, Verdin $M$, Riegel $B$, Fesard $P$, Moinardeau $V$, Delehaye B, Adnet P, Krivosic-Horber R: Hemodynamic effects of genu-pectoral position during the surgery of lumbar disk herniation: Spinal anesthesia versus general anesthesia. Agressologie 1:49-50, 1994 
2. Bonhomme V, Doll A, Dewandre PY, Brichant JF, Ghassempour $K$, Hans P: Epidural administration of low dose morphine combined with clonidine for postoperative analgesia after lumbar disc surgery. J Neurosurg Anesthesiol 14:1-6, 2002

3. Covino BG: Rationale for spinal anesthesia. Int Anesthesiol Clin 27:8-12, 1989

4. Hassi N, Badaoui R, Cagny-Bellet A, Sifeddine S, Ossart M: Spinal anesthesia for disc herniation and lumbar laminectomy. Apropos of 77 cases. Cah Anesthesiol 43:221-225,1995

5. Jellish WS, Shea JF: Spinal anaesthesia for spinal surgery. Best Pract Res Clin Anaesthesiol 17:323-334, 2003

6. Jellish WS, Thalji Z, Stevenson K, Shea J: A prospective randomized study comparing short- and intermediate-term perioperative outcome variable safter spinal or general anesthesia for lumbar disc and laminectomy surgery. Anesth Analg 83:559-564, 1996

7. Kleinstueck FS, Fekete T, Jeszenszky D, Mannion AF, Grob D, Lattig F, Mutter U, Porchet F: The outcome of decompression surgery for lumbar herniated disc is influenced by the level of concomitant preoperative low back pain. Eur Spine J 20: 1166-1173, 2011

8. Mahan KT, Wang J: Spinal morphine anesthesia and urinary retention. J Am Pediatr Med Assoc 83:607-614, 1993

9. McLain RF, Kalfas I, Bell GR, Tetzlaff JE, Yoon HJ, Rana M: Comparison of spinal and general anesthesia in lumbar laminectomy surgery: A case-controlled analysis of 400 patients. J Neurosurg Spine 2:17-22, 2005

10. Rassias AJ, Procopio MA: Stress response and optimization of perioperative care. Dis Mon 49:522-554, 2003

11. Riding JE: Minor complications of general anesthesia. $\mathrm{Br} J$ Anaesth 47:91-101, 1975

12. Rung GW, Williams D, Gelb DE, Grubb M: Isobaric spinal anesthesia for lumbar disk surgery. Anesth Analg 85: 1165-1166, 1997
13. Schuster M, Gottschalk A, Berger J, Standl T: A retrospective comparison of costs for regional and general anesthesia techniques. Anesth Analg 100:786-794, 2005

14. Scott NB, Kehlet $H$ : Regional anesthesia and surgical morbidity. Br J Surg 75:299-304, 1990

15. Silver DJ, Dunsmore RH, Dickson CM: Spinal anesthesia for lumbar disc surgery: Review of 576 operations. Anesth Analg 55:550-554, 1976

16. Smrcka M, Baudysovå $O$, Jurån V, Vidlåk M, Gål R, Smrcka $\mathrm{V}$ : Lumbar disc surgery in regional anesthesia: 40 years of experience. Acta Neurochir (Wien) 143:377-381,2001

17. Spencer DL, Bernstein AJ: Lumbar intervertebral disc surgery. In: Bridwell KH, DeWald RL (eds), Text book of Spinal Surgery. 2 nd ed. Philadelphia: Lippincott-Raven, 1997:1547-1561

18. Tetzlaff JE, Dilger JA, Kodsy M, al-Bataineh J, Yoon HJ, Bell GR: Spinal anesthesia for elective lumbar spine surgery. J Clin Anesth 10:666-669,1998

19. Tetzlaff JE, O'Hara JF, Yoon HJ, Schubert A: Heart rate variability and the prone position under general versus spinal anesthesia. J Clin Anesth 10:656-659, 1998

20. Tzovaras G, Fafoulakis F, Pratras K, Georgopoulou S, Stamatiou G, Hatzitheofilou C: Spinal vs general anesthesia for laparoscopic cholecystectomy: Interim analysis of a controlled randomized trial. Arch Surg 143:497-501, 2008

21. Weinstein JN, Lurie JD, Tosteson TD, Skinner JS, Hanscom B, Tosteson AN, Herkowitz H, Fischgrund J, Cammisa FP, Albert T, Deyo RA: Surgical vs nonoperative treatment for lumbar disk herniation: The Spine Patient Outcomes Research Trial (SPORT) observational cohort: JAMA 296:2451-2459, 2006

22. Yilmaz C, Buyrukcu SO, Cansever T, Gulsen S, Altinors N, Caner $\mathrm{H}$ : Lumbar microdiscectomy with spinal anesthesia: Comparison of prone and knee-chest positions in means of hemodynamic and respiratory function. Spine (Phila Pa 1976) $35: 1176-1184,2010$ 